- Entomologica Fennica. 9.XII.1993

\title{
Nomenclatural note on the genus Moissonia Reuter (Hemiptera, Miridae, Phylinae)
}

\author{
R. E. Linnavuori \& M. M. Al-Safadi
}

Linnavuori, R. E. \& Al-Safadi, M. M. 1993: Nomenclatural note on the genus Moissonia Reuter (Hemiptera, Miridae, Phylinae). — Entomol. Fennica 4:233234.

The taxonomic position of the genus Moissonia Reuter is discussed. Ellenia Reuter, Marshalliella Poppius, and Melanotrichiella Poppius are junior synonyms of Moissonia. Marshalliella obscuricornis Poppius and Psallus labeculus Odhiambo are synonyms of Moissonia punctata (Fieber).

R. E. Linnavuori, Somersoja, FIN-21220 Raisio 22, Finland

M. M. Al-Safadi, P.O. Box 392, Sana'a, Republic of Yemen

The article is based on field work made by the senior author in 1992 in the Republic of Yemen. A zoogeographically interesting synonymy between the genera Moissonia Reuter and Ellenia Reuter was detected.

\section{Moissonia Reuter, 1894}

Moissonia Reuter 1894:148. Type species: Agalliastes punctatus Fieber.

Ellenia Reuter 1910:168. Type species: Capsus cuneatus Stål, syn. n.

Marshalliella Poppius 1914:75. Type species: M. obscuricornis Poppius, syn. $n$.

Melanotrichiella Poppius 1914:80. Type species: $M$. annulicornis Poppius, syn. $\mathrm{n}$.

Reuter (1894:148) described the genus Moissonia with Agalliastes punctatus Fieber as the type species. The genus has remained enigmatic ever since. Wagner (1975:65-66), for example, misinterpreted the claw structure (Fig. 1b) regarding the fleshy parempodia as pulvilli, and located the genus close to Campylomma Reuter with which it is not actually related. Moissonia punctata was formerly known only from Spain (Malaga and Alicante) and Algeria (Oran). Prof. Attilio Cara- pezza, Palermo, recently found the species in Sicily and kindly sent us several specimens. An examination of these surprisingly revealed that Moissonia is identical with the well-known intertropical genus Ellenia Reuter. The type species $M$. punctata is even a senior synonym of the common East African species E. obscuricornis (Poppius), which is distributed from South Africa to Ethiopia and Yemen, and, undoubtedly during the Pluvial period along the Red Sea hills, even to the Mediterranean area. The genera Marshalliella Poppius and Melanotrichiella Poppius were declared synonyms of Ellenia in Carvalho 1952:76 and Linnavuori 1973:89-90 and 1975:87.

\section{M. punctata (Fieber, 1861)}

Fig. 1a

Agalliastes punctatus Fieber 1861:311.

Moissonia punctata Reuter 1894:148.

Marshalliella obscuricornis Poppius 1914:76, syn. n.

Psallus labeculus Odhiambo 1959:518-521, syn. n. (synonymized with Marshalliella obscuricornis in Linnavuori 1973:90)

Material studied: Ethiopia: Sululta, 2 exx, 11.VI.1963, Linnavuori. Yemen: Sana'a, 1 ex, VII-IX.1991, A. van 

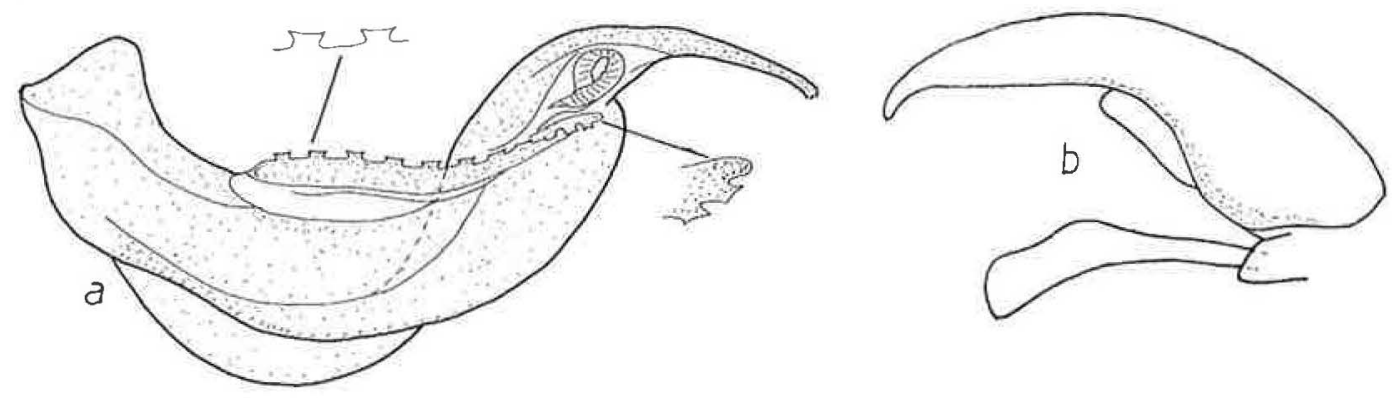

Fig. 1. Moissonia punctata (Fieber): a) vesica (ex from Sana'a). - M. kilimana (Poppius): b) claw.

Harten. Italy: Sicily, Etna, Rif. Sapienza, alt. 1600 m, several exx, 24.VII.1990, A. Carapezza.

Redescription in Schuh 1974:158-159. Vesica illustrated in Fig. 1a.

Biology: Undoubtedly restricted to the Compositae genus Senecio. Schuh found it on Senecio burchelli and S. angustifolius in South Africa, Carapezza on $S$. aetnensis in Sicily.

Distribution: East African. A common species in South and East Africa.

\section{References}

Carvalho, J. C. M. 1952: On the major classification of the Miridae (Hemiptera). — An. Acad. Brasil. Sci. 24:31110.

Fieber, F. X. 1861: Die europäischen Hemipteren. Halbflügen (Rhynchota Heteroptera) II: 113-444. Druch und Verlag von Carl Gerold's Sohn. Wien.

Linnavuori, R. E. 1973: A collection of Heteroptera from Katanga, with remarks on some species from other parts of the Ethiopian Region. - Ann. Entomol. Fennici 39:70-94.

- 1975: Hemiptera of the Sudan, with remarks on some species of the adjacent countries. 4. Miridae and Isometopidae. - Ann. Zool. Fennici 12:1-118.

Odhiambo, T. 1959: Notes on the East African Miridae (Hemiptera) XIII. Twelve new species of Psallus Fieber. - Ann. Mag. Nat. Hist. (13)2:513-544.

Poppius, B. 1914: Die Miriden der Äthiopischen Region II. - Acta Soc. Sci. Fennicae 44:1-136.

Reuter, O. M. 1894: Ad Cognitionem Capsidarum II. Capsidae palaearcticae. - Rev. d'Entomol. 13:128-152.

- 1910: Neue Beiträge zur Phylogenie und Systematik der Miriden nebst einleitenden Bemerkungen über die Phylogenie der Heteropteren-Familien. Mit einer Stammbaum. - Acta Soc. Sci. Fennicae 37(3): 1-169.

Schuh, R. T. 1974: The Orthotylinae and Phylinae (Hemiptera, Miridae) of South Africa with a phylogenetic analysis of the ant-mimetic tribes of the two subfamilies for the world. - Entomol. Americana 47:1-332.

Wagner, E. 1975: Die Miridae Hahn, 1831, des Mittelmeerraumes und der Makaronesischen Inseln (Hemiptera, Heteroptera). Teil 3. - Entomol. Abh. Staatl. Mus. Tierkunde Dresden 40, Suppl., 483 pp.

Received 29.XII.1992 